\title{
Kwalifikowanie technologii spawania wg PN-EN ISO 15614-8 na przykładzie płyt sitowych w U-rurowych wymiennikach ciepła
}

\author{
Qualification of welding procedures \\ acc. to PN-EN ISO 15614-8 - an example \\ of tube plate used in U-tube heat exchangers
}

\section{Streszczenie}

W artykule przedstawiono charakterystykę normy PN-EN ISO 15614-8:2005 Specyfikacja i kwalifikowanie technologii spawania metali. Badanie technologii spawania. Część 8: Spawanie rur z płytami sitowymi [1]. Zaprezentowano algorytm postępowania w przypadku stosowania tej normy, i podano warunki, które uzasadniają wybór normy PN-EN ISO 15614-8 do zatwierdzania technologii spawania. Przedstawiono przykład złączy spawanych stosowanych w połączeniach typu dno sitowe-rury oraz wyniki badań kwalifikacyjnych dla połączenia dna sitowego ze stali kotłowej P355NH z rurami z austenitycznej stali odpornej na korozję 316L.

\section{Wstęp}

Płyty sitowe, nazywane również dnami sitowymi lub ścianami sitowymi, to elementy konstrukcyjne różnych rodzajów wymienników ciepła. Do tych elementów montowane są na stałe lub z możliwością wymiany rury, w których znajduje się jeden z czynników roboczych. Stanowią one integralną część całego urządzenia i wymagają szczególnej uwagi podczas wytwarzania. Na rysunku 1 przedstawiono przykład typowego wymiennika ciepła z układem U-rurowym, a na rysunku 2 widok płyty sitowej połączonej $z$ rurami. Rury montowane w płycie sitowej muszą charakteryzować

Dr inż. Grzegorz Rogalski, dr inż. Dariusz Fydrych - Politechnika Gdańska.

\section{Abstract}

The paper presents the characteristic of the PN-EN ISO 15614-8:2005 „Specification and qualification of weIding procedures for metallic materials - Welding procedure test - Part 8: Welding of tubes to tube-plate joints [1]. An algorithm of procedures needed to apply this standard is presented and the conditions that justify the choice of the PN-EN ISO 15614-8 for qualification of welding procedures are given. An example of welded tube to tube-plate joints and the results of qualifying tests for the connection of tube-plate (P355NH) with austenitic tubes (316L) are shown.

się odpowiednimi właściwościami, a proces ich wytwarzania musi być odpowiednio potwierdzony [2, 3].

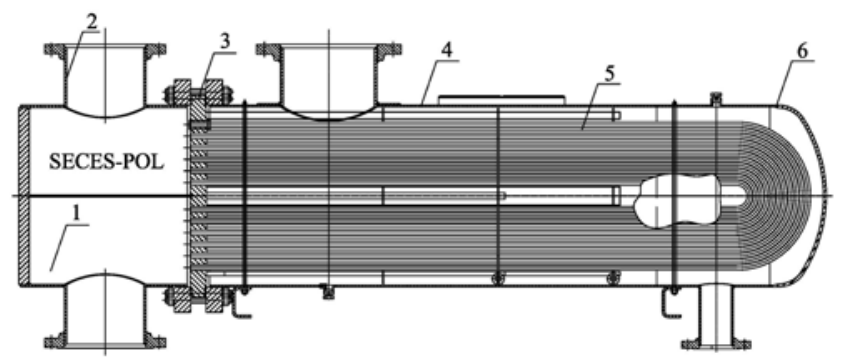

Rys. 1. Płaszczowy wymiennik ciepła z U-rurową wężownicą produkowany przez firmę SECES-POL: 1 - głowica, 2 - króciec, 3 - płyta sitowa, 4 - płaszcz zbiornika, 5 - wężownica U-rurowa, 6 - dennica [4]

Fig. 1. Shell and tube heat exchanger with U-tube coil produced by SECES-POL: 1 - head; 2 - nozzle, 3 - tube-plate, 4 - shell, 5 - U-tube coil, 6 - bottom [4] 


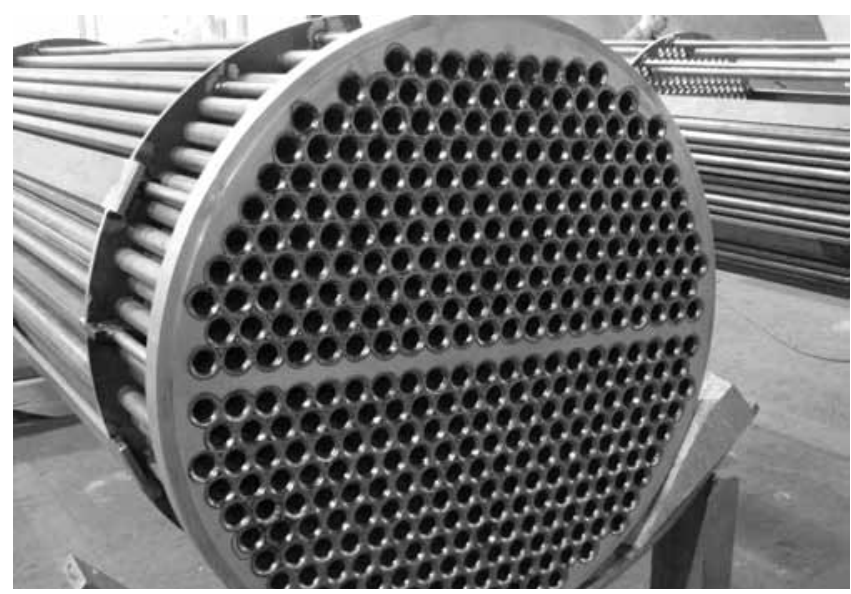

Rys. 2. Płyta sitowa ze stali $\mathrm{P} 355 \mathrm{NH}$ połączona z rurami ze stali nierdzewnej [4]

Fig. 2. View of tubes to tube-plate joints. Steel P355NH welded with stainless steel tubes [4]

Do najczęściej stosowanych technologii mocowania rur w płytach sitowych można zaliczyć: rozpęczanie, spawanie, rozwalcowywanie, lutowanie, zadławienie, zgrzewanie wybuchowe oraz klejenie.

Rozpęczanie to technologia, która znajduje zastosowanie do łączenia rur o małych średnicach $(10 \div 12$ $\mathrm{mm})$. Wykonuje się ją stożkowym przebijakiem. Zastosowanie procesu lutowania ograniczone jest temperaturą topnienia lutu, która dla lutowania miękkiego jest niska. Najczęściej stosuje się technologię spawania po uprzednim zlikwidowaniu luzu pomiędzy otworem a rurą (przywalcowanie) oraz pełne rozwalcowywanie. Ta technologia umożliwia konfigurację materiałową, której nie można zastosować $w$ procesie spawania, np. płyta sitowa wykonana jest ze stali kotłowej, a rury z miedzi lub mosiądzu. Jest to możliwe pod warunkiem, że granica plastyczności i twardość płyty są większe dla rury. Aby spełnić te warunki w niektórych przypadkach stosuje się wyżarzanie zmiękczające końców rur. Proces spawania wykorzystywany jest do łączenia rur z płytą sitową przy wysokim ciśnieniu i temperaturze pracy wymiennika $\left(p>80 \cdot 10^{5} \mathrm{~Pa} ; \mathrm{t}>350^{\circ} \mathrm{C}\right)$. Dodatkowo można stosować przed procesem spawania rozwalcowywanie [5].

Tak szeroki wybór metod łączenia wynika z czynników technologiczno-konstrukcyjnych, do których można zaliczyć:

- gatunek materiału (grupę materiałową, której wybór najczęściej wynika z parametrów oraz warunków pracy wymiennika),

- właściwości mechaniczne ze szczególnym uwzględnieniem granicy plastyczności $R_{e}$ (informacja szczególnie istotna dla procesu rozwalcowywania),

- możliwość spajania zastosowanych materiałów (spawanie, lutowanie, zgrzewanie wybuchowe),

- warunki pracy wymiennika,

- geometrię połączenia, np. kształt oraz wymiary rur lub płyty sitowej.

Zakres materiałów podstawowych możliwych do zastosowania na poszczególne elementy jest bardzo szeroki. Rury stosowane w wymiennikach ciepła mogą być
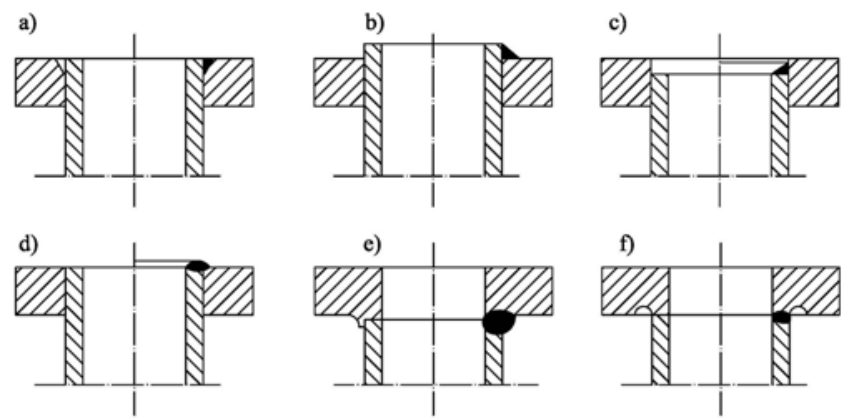

Rys. 3. Przykłady konfiguracji połączenia rury z płytą sitową: a) spoina czołowa; b), c) spoina pachwinowa; d) spoina brzegowa; e) spoina czołowa sita z odkuwanymi występami; f) połączenie spoiną czołową z podcięciem płyty sitowej $[5 \div 7]$

Fig. 3. Examples of tubes to tube-plate joints: a) butt weld; b), c) fillet

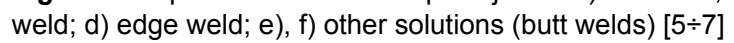

wykonane ze stali niestopowych (S355J2H itp.), stali wysokostopowych austenitycznych odpornych na korozję (321, 316 itp.), stali dupleks (np. 2305), tytanu i jego stopów (Grade 1, Grade 2), niklu i jego stopów (np. Incolloy $800 \mathrm{HT}$ ), miedzi, mosiądzu i innych metali spełniających kryteria technologiczno-konstrukcyjne. Podobna sytuacja dotyczy płyt sitowych. Możliwość zestawienia różnych połączeń materiałów wymusza stosowanie odpowiednio dobranych technologii łączenia, które mogą wynikać ze specyfikacji technicznych lub odpowiednich norm przedmiotowych (np. dotyczących projektowania). Przykładami tego rodzaju dokumentów mogą być: ASME Sec. VIII div. I (zał. A) [6] oraz norma PN-EN 13445-3 (tab. A-5) [7]. Wybrane przykłady sposobów łączenia płyty sitowej z rurami wg wymienionych standardów przedstawiono na rysunku 3.

Ze względu na bardzo duże znaczenie połączeń rur z płytami sitowymi stworzono odpowiednie przepisy dotyczące kwalifikowania technologii spawania. Są one zawarte w przepisach ASME Sec. IX (QW-288; QW-303.5; QW-193) oraz jako standard międzynarodowy PN-EN ISO 15614-8:2005 [8].

\section{Charakterystyka normy PN-EN ISO 15614-8}

Norma PN-EN ISO 15614-8:2005 dotyczy kwalifikowania technologii spawania rur z płytami sitowymi. Nie miała ona odpowiednika w serii norm PN-EN 288. Jest normą zharmonizowaną $z$ dyrektywą ciśnieniową 97/23/WE. Umożliwia to zastosowanie jej do kwalifikowania procesu spawania płyt sitowych z rurami przy budowie urządzeń ciśnieniowych, np. wymienników ciepła. Norma ta została przygotowana przez KT 165 ds. technologii spawalniczych, zatwierdzona przez Prezesa PKN 02.12.2004 r. i opublikowana 24.01.2005 r. 


\section{Zakres merytoryczny}

W dokumencie PN-EN ISO 15614-8 ustalono wymagania dla kwalifikowania technologii spawania den sitowych z rurami za pomocą jej badania dla spawania łukowego ręcznego, częściowo zmechanizowanego, w pełni zmechanizowanego oraz automatycznego. Tego rodzaju kwalifikowanie może obejmować złącza przenoszące wszystkie obciążenia, bądź spoiny wykonane jako uszczelniające. Należy zaznaczyć, że norma ta ma zastosowanie do spawania rur z płytami sitowymi z odstępem. W przypadku połączenia bez odstępu pomiędzy elementami zaleca się, aby procedura zatwierdzania technologii spawania była ujęta w dokumentacji. Ograniczenie stosowania omawianego standardu dotyczy spawania rur z płytą sitową z odkuwanymi występami (rys. 3e). Norma zaleca wtedy uwzględnienie spawania $z$ naprawą technologiczną.

Normy przywołane przez dokument dotyczą certyfikowania spawaczy, klasyfikacji gazów stosowanych w procesach spawalniczych, badań niszczących i nieniszczących, podziału materiałów metalowych na grupy materiałowe, przygotowania elementów do spawania, poziomów jakości złączy spawanych oraz kwalifikowania technologii spawania i przygotowania instrukcji technologicznej spawania WPS. Dokument jednoznacznie określa stosowanie norm przywołanych, które są datowane i niedatowane. W przypadku standardów niedatowanych stosuje się ostatnie wydanie powołanej publikacji. Inaczej wygląda zastosowanie norm datowanych. Najnowsze wydania publikacji datowanych moga być stosowane tylko wtedy, kiedy norma PN-EN ISO 15614-8 zostanie zmieniona lub znowelizowana oraz normy te zostana w niej przywołane. W innym przypadku należy stosować te dokumenty datowane, które są przywołane w normie.

\section{Stosowane symbole}

W celu ujednolicenia oznaczeń wielkości geometrycznych oraz innych zmiennych norma wprowadza symbole zestawione $\mathrm{w}$ tablicy I i pokazano na rysunkach $4 \div 6$.
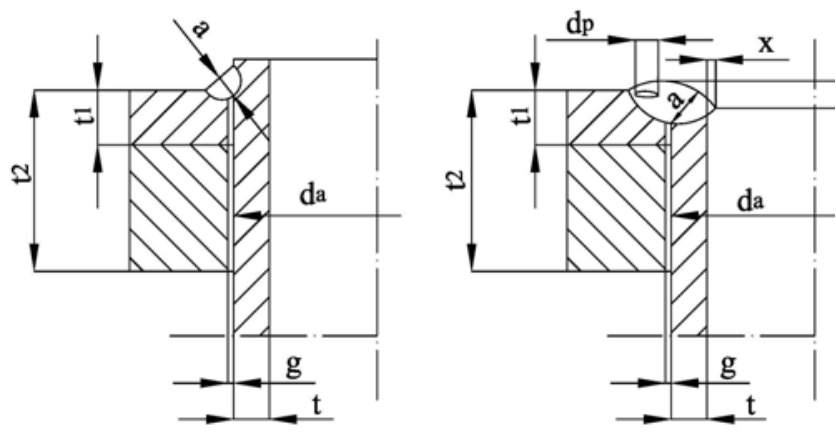

Rys. 4. Przykładowe połączenia spawane płyty sitowej z rurą, przedstawiające wielkości oznaczone symbolami zdefiniowanymi w tablicy I Fig. 4. Examples of tubes to tube-plate joints with symbols from table I
Tablica I. Symbole stosowane w normie PN-EN ISO 15614-8 Table I. Symbols used in PN-EN ISO 15614-8 standard

\begin{tabular}{|c|c|c|}
\hline Symbol & Opis & Jednostka \\
\hline a & $\begin{array}{l}\text { grubość spoiny (w tym przypadku odległość } \\
\text { między najniższym punktem grani spoiny a po- } \\
\text { wierzchnią spoiny) }\end{array}$ & $\mathrm{mm}$ \\
\hline$d_{p}$ & wielkość pęcherza & $\mathrm{mm}$ \\
\hline$d_{a}$ & średnica zewnętrzna rury & $\mathrm{mm}$ \\
\hline $\mathrm{d}_{1}$ & minimalna odległość między dwoma rurami & $\mathrm{mm}$ \\
\hline g & szczelina między rurą a płytą sitową & $\mathrm{mm}$ \\
\hline $\mathrm{s}_{\mathrm{p}}$ & początek ściegu graniowego & - \\
\hline $\mathrm{t}$ & grubość ścianki rury & $\mathrm{mm}$ \\
\hline $\mathrm{t}_{1}$ & grubość plateru & $\mathrm{mm}$ \\
\hline $\mathrm{t}_{2}$ & grubość płyty sitowej & $\mathrm{mm}$ \\
\hline$x$ & nawis & $\mathrm{mm}$ \\
\hline \multicolumn{3}{|c|}{$\begin{array}{l}\text { Uwaga: Wielkości oznaczone wymienionymi symbolami przedsta- } \\
\text { wiono na rysunkach } 4 \div 6 \text {. }\end{array}$} \\
\hline
\end{tabular}

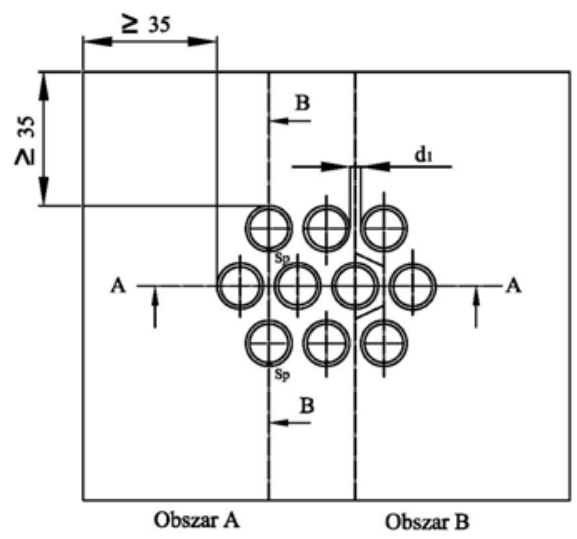

Rys. 5. Złącze próbne do kwalifikowania technologii spawania w układzie (podziałce) trójkątnym: $d_{1}$ - minimalna odległość pomiędzy dwoma rurami, $S_{p}$ - początek ściegu graniowego, A-A, B-B - przykłady umiejscowienia linii cięcia do wykonania zgładów metalograficznych makroskopowych

Fig. 5. Test joint for tube ends on triangular pitch: $d_{1}-$ minimal distance between two tubes, $S_{p}$ - starting point of the root run, A-A, $\mathrm{B}-\mathrm{B}$ - ground sections of a test specimen (examples for the location of the cut lines)

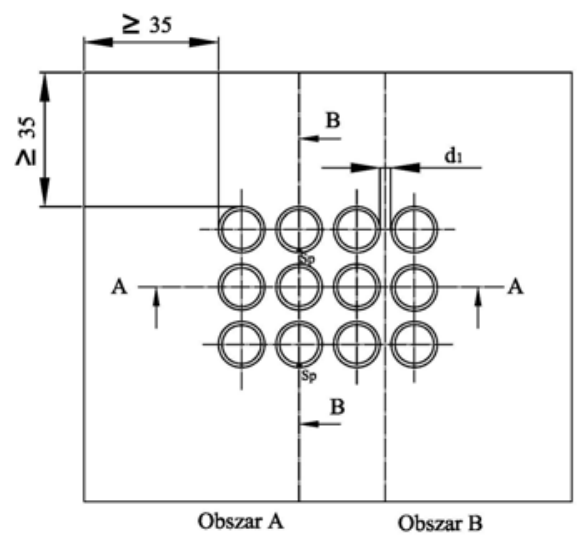

Rys. 6. Złącze próbne do kwalifikowania technologii spawania w układzie (podziałce) kwadratowym: $d_{1}$ - minimalna odległość pomiędzy dwoma rurami, $S_{p}$ - początek ściegu graniowego, A-A, B-B - przykłady umiejscowienia linii cięcia do wykonania zgładów metalograficznych makroskopowych

Fig. 6. Test joint for tube ends on square pitch: $d_{1}-$ minimal distance between two tubes, $S_{p}$ - starting point of the root run, A-A, B-B - ground sections of a test specimen (examples for the location of the cut lines) 


\section{Zasady kwalifikowania technologii spawania}

Kwalifikowanie technologii spawania powinno być oparte na wstępnej instrukcji technologicznej spawania pWPS. Należy ją opracować zgodnie z wytycznymi zawartymi w normie prEN ISO 15609-1:2000 [9]. Powinna ona zawierać zmienne podane w pkt. 4.2 oraz 4.3 omawianej normy. Sam proces zatwierdzania technologii spawania powinien być przeprowadzony przez egzaminatora lub jednostkę egzaminującą zgodnie $z$ dokumentacją konstrukcyjną lub normą dotyczącą stosowania. Spawacze i operatorzy powinni posiadać odpowiednie kwalifikacje zdobyte zgodnie z wytycznymi odpowiednich norm przedmiotowych. Dla spawaczy są to: EN 287-1 [10] (prEN ISO 9606-1), EN 287-2 [11], EN ISO 9606-3 [12], EN ISO 9606-4 [13], EN ISO 9606-5 [14], natomiast dla operatorów: EN 1418 [15]. Złącza należy przygotować wg normy EN 29692 [16], a ich konstrukcje wg EN 1708-1 [17].

Tablica II. Zakres badań dla złączy spawanych wg PN-EN ISO 15614-8

Table II. Range of testing for welded joints acc. to PN-EN ISO 15614-8

\begin{tabular}{|c|c|c|}
\hline $\begin{array}{l}\text { Rodzaj } \\
\text { badań }\end{array}$ & $\begin{array}{l}\text { Zakres } \\
\text { badań }\end{array}$ & Uwagi \\
\hline $\begin{array}{l}\text { Badania } \\
\text { wizualne } \\
\text { (VT) }\end{array}$ & $100 \%$ & $\begin{array}{l}\text { Badania należy wykonać przed pocię- } \\
\text { ciem próbki do badań, po odpowied- } \\
\text { nim oczyszczeniu powierzchni i po ob- } \\
\text { róbce cieplnej, jeśli była wymagana. } \\
\text { Poziom akceptacji przyjąć z tablicy I; } \\
\text { pkt } 7.2 .2 \text { omawianej normy. }\end{array}$ \\
\hline $\begin{array}{c}\text { Badania } \\
\text { penetracyjne } \\
\text { (UT) }\end{array}$ & $100 \%$ & $\begin{array}{l}\text { Przeprowadzić zgodnie z EN 571-1. } \\
\text { Jakiekolwiek wskazania w spoinie } \\
\text { i SWC są niedopuszczalne. }\end{array}$ \\
\hline $\begin{array}{l}\text { Badania } \\
\text { radiograficzne } \\
\text { (RT) }\end{array}$ & \begin{tabular}{|}
$100 \%$ z \\
pominięciem \\
spoin do \\
próby \\
wyciskania
\end{tabular} & $\begin{array}{l}\text { Przeprowadzić zgodnie z EN } 1435 . \\
\text { Badania obowiązują dla wszystkich } \\
\text { spoin oprócz tych, które przeznaczone } \\
\text { są do wykonania próby wyciskania. } \\
\text { Poziom akceptacji przyjąć z tablicy II; } \\
\text { pkt 7.2.4 omawianej normy. }\end{array}$ \\
\hline $\begin{array}{l}\text { Badania } \\
\text { makrosko- } \\
\text { powe }\end{array}$ & $\begin{array}{l}\text { Podano na } \\
\text { rys. } 4 \text { i. } 5 \\
\text { (linie cięcia } \\
\text { A-A, B-B) }\end{array}$ & $\begin{array}{l}\text { Przeprowadzić zgodnie z EN } 1321 . \\
\text { Cięcie mechaniczne lub obróbka skra- } \\
\text { waniem. } \\
\text { Linia cięcia musi przebiegać przez } \\
\text { dwa punkty rozpoczęcia spawania } \\
\text { ściegów graniowych. } \\
\text { Poziom akceptacji przyjąć z tablicy III; } \\
\text { pkt } 7.2 .5 \text { omawianej normy. }\end{array}$ \\
\hline $\begin{array}{l}\text { Badania } \\
\text { twardości }\end{array}$ & $\begin{array}{c}\text { Pomiar twar- } \\
\text { dości spo- } \\
\text { iny, obu } \\
\text { SWC oraz } \\
\text { materiału ro- } \\
\text { dzimego }\end{array}$ & $\begin{array}{l}\text { Przeprowadzić zgodnie z EN 1043-1, } \\
\text { jedynie dla grup stali } 2 \div 7 \text { oraz dla złą- } \\
\text { czy niejednorodnych stali austenitycz- } \\
\text { nych ze stalami ferrytycznymi wg CR } \\
\text { ISO } 15608 \text {. } \\
\text { Poziom akceptacji przyjąć z tablicy } 2 \\
\text { normy prEN ISO } 15614-1 \text {. }\end{array}$ \\
\hline $\begin{array}{l}\text { Badania wy- } \\
\text { pychania lub } \\
\text { wyciagania }\end{array}$ & \begin{tabular}{|c|} 
Podaje \\
specyfikacja \\
techniczna
\end{tabular} & $\begin{array}{l}\text { Poziom akceptacji: określony w specy- } \\
\text { fikacji technicznej. }\end{array}$ \\
\hline
\end{tabular}

W budowie wymienników ciepła najczęściej stosuje się dwa rodzaje układów rur. Pierwszy z nich to układ trójkątny (rys. 5), drugi to układ kwadratowy (rys. 6). Oba ujęte są w omawianej normie, a liczba rur spawanych do płyty sitowej jest uzależniona od średnicy zewnętrznej rury. Dla rur w układzie (podziałce) trójkątnym i średnicy zewnętrznej rury $D<40 \mathrm{~mm}$ powinno się spawać 10 rur do płyty. Dla rur o średnicy $\mathrm{D} \geq 40 \mathrm{~mm}$ należy przyspawać minimum 7 końców rur (obszar A na rys. 5). Inaczej wygląda sytuacja w przypadku stosowania układu (podziałki) kwadratowego. Dla rur o średnicy zewnętrznej $D<40 \mathrm{~mm}$ należy przyspawać 12 rur do płyty sitowej, a dla rur o średnicy $D \geq 40 \mathrm{~mm}$ minimum 9 końców rur (obszar A rys. 6). Odległość pomiędzy osiami otworów wynika ze specyfikacji technicznej dotyczącej projektowania i podawana jest przez konstruktora.

\section{Zakres badań}

W celu zatwierdzenia technologii spawania po wykonaniu złączy próbnych należy wykonać wskazane badania potwierdzające odpowiedni poziom jakości. W normie przedstawiono rodzaj badań, ich zakres oraz poziomy akceptacji. W tablicy II przedstawiono charakterystykę badań ujętych w normie PN-EN ISO 15614-8.

\section{Zakres kwalifikacji}

Norma PN-EN ISO 15614-8:2005 uwzględnia w zakresie kwalifikacji następujące zmienne:

- grupę materiałową,

- wymiary geometryczne płyt sitowych i rur,

- podziałkę (układ) spawanych rur,

- metodę spawania,

- pozycję spawania płyty sitowej,

- typ złącza,

- gatunek materiału dodatkowego do spawania,

- rodzaj i biegunowość prądu spawania,

- sposób doprowadzenia ciepła,

- temperaturę podgrzewania wstępnego,

- temperaturę międzyściegową,

- obróbkę cieplną po spawaniu,

- rodzaj gazu osłonowego.

Do celów omawianej normy do klasyfikacji materiałów podstawowych stosuje się CR ISO 15608 [18]. Zakres kwalifikowania powinien być zgodny z odpowiednim arkuszem normy prEN ISO 15614 [19]. Jednym z ważnych aspektów zakresu kwalifikacji jest rodzaj użytej podziałki (układu rur w płycie sitowej). Spawanie wg określonego rodzaju podziałki kwalifikuje inne podziałki, pod warunkiem, że najmniejszy odstęp pomiędzy dwoma rurami $\left(\mathrm{d}_{1}\right)$ nie jest mniejszy niż w kwalifikowanej technologii. Zmiana 
Tablica III. Zakres kwalifikacji wielkości geometrycznych płyt sitowych i rur

Table III. Range of qualification for geometrical details of tube-plates and tubes

\begin{tabular}{|l|c|c|}
\hline \multicolumn{1}{|c|}{ Oznaczenie } & $\begin{array}{c}\text { Złącze } \\
\text { próbne } \\
\mathrm{mm}\end{array}$ & $\begin{array}{c}\text { Zakres } \\
\text { kwalifikacji } \\
\mathrm{mm}\end{array}$ \\
\hline Grubość plateru & $\begin{array}{r}\mathrm{t}_{1}<3 \\
\mathrm{t}_{1} \geq 3\end{array}$ & $\begin{array}{c}\geq \mathrm{t}_{1} \\
\geq 3\end{array}$ \\
\hline Grubość płyty sitowej & $\begin{array}{c}\mathrm{t}_{2}<35 \\
\mathrm{t}_{2} \geq 35\end{array}$ & $\begin{array}{c}\geq \mathrm{t}_{2} \\
\geq 35\end{array}$ \\
\hline $\begin{array}{l}\text { Grubość ścianki rury do spawania } \\
\text { ręcznego }\end{array}$ & $\mathrm{t}$ & $0,5 \mathrm{t} \div 2 \mathrm{t}$ \\
\hline $\begin{array}{l}\text { Grubość ścianki rury do spawania } \\
\text { zmechanizowanego lub automa- } \\
\text { tycznego }\end{array}$ & $\mathrm{t}$ & $\mathrm{t} \pm 0,2 \mathrm{t}$ \\
\hline Zewnętrzna średnica rury & $\mathrm{d}_{\mathrm{a}}$ & $\geq \mathrm{d}_{\mathrm{a}}$ \\
\hline
\end{tabular}

następujących zmiennych powoduje ponowne kwalifikowanie technologii spawania:

- metody (metod) spawania użytej podczas wykonywania złącza próbnego,

- typu złącza,

- pozycji spawania,

- rodzaju i biegunowości prądu spawania,

- rodzaju otuliny elektrody,

- średnicy materiału dodatkowego do spawania,

- rodzaju gazu osłonowego wg EN 439 [20].

Zakres kwalifikacji dla wielkości geometrycznych przedstawiono w tablicy III.

W przypadku doprowadzenia ciepła wytyczne obowiązują tylko wtedy, kiedy wymagana jest jego kontrola. Może tak być np. gdy stawia, się określone wymagania dla twardości po procesie spawania. W takim przypadku stosuje się dolną granicę ilości doprowadzonego ciepła lub przyjmuje, że ilość ciepła może być o $25 \%$ większa niż stosowana podczas wykonywania złącza próbnego. Wtedy stosowanie podgrzewania wstępnego dotyczy dolnej granicy temperatury podgrzewania. Inaczej jest, gdy w procesie spawania rury z płytą sitową należy uwzględnić temperaturę międzyściegową. $W$ tym przypadku kwalifikowanie dotyczy górnej granicy temperatury międzyściegowej uzyskanej podczas wykonywania złącza próbnego. Dla obróbki cieplnej kryteria zatwierdzenia technologii spawania sa następujące: badanie technologii z obróbką cieplną nie kwalifikuje technologii bez obróbki cieplnej i odwrotnie.

\section{Algorytm postępowania przy kwalifikowaniu technologii spawania}

Wymagania związane z kwalifikowaniem technologii spawania połączenia płyty sitowej z rurami wynikają najczęściej ze specyfikacji technicznej, ale

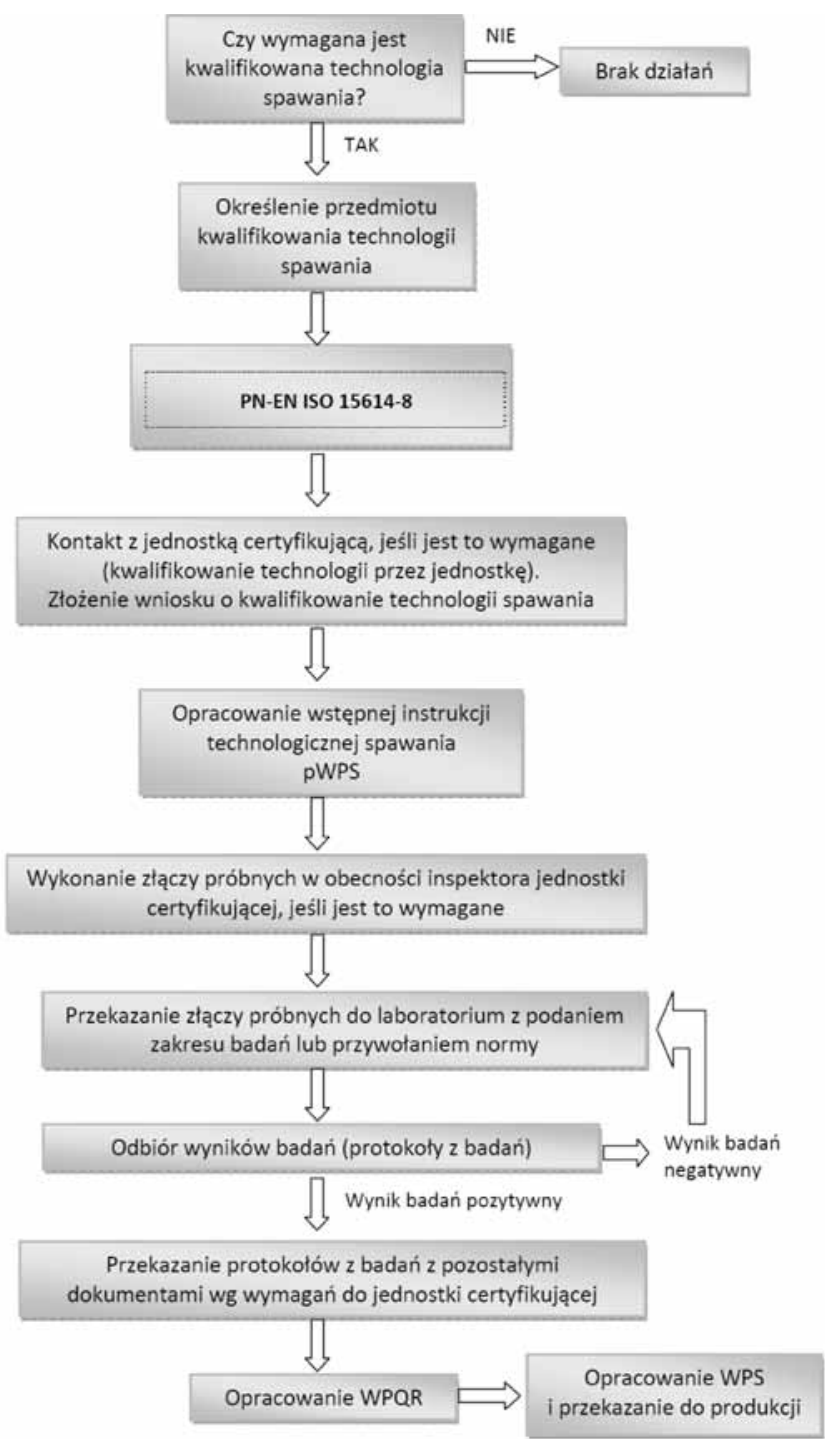

Rys. 7. Algorytm postępowania w przypadku kwalifikowania technologii spawania wg PN-EN ISO 15614-8

Fig. 7. Scheme of qualification of welding procedures according to PN-EN ISO 15614-8

mogą również być narzucone przez zleceniodawcę. Po dokładnej analizie dokumentacji technicznej i stwierdzeniu, że wymagana jest zatwierdzona technologia spawania (np. przez jednostkę certyfikującą), należy określić wszystkie zmienne zasadnicze mające wpływ na zakres uznania. Przed procesem certyfikacji należy zwrócić szczególną uwagę na:

- grupę materiałową dla płyty sitowej oraz rur (zgodność pomiędzy spawanymi materiałami),

- wielkości geometryczne płyty sitowej oraz rur (grubość, średnica),

- układ (podziałkę) spawanych rur (trójkątny, kwadratowy),

- metodę spawania z uwzględnieniem jej modyfikacji przez zautomatyzowanie lub zrobotyzowanie,

- pozycję spawania płyty sitowej,

- rodzaj złącza oraz spoiny, 
- zabiegi technologiczne towarzyszące procesowi spawania, np. podgrzewanie wstępne, obróbka cieplna po spawaniu, pomiar temperatury międzyściegowej itp.,

- zastosowanie materiału dodatkowego do spawania,

- pozostałe zmienne wynikające np. z warunków spawania,

Zwykle kwalifikowanie technologii spawania wykonuje się pod nadzorem jednostki certyfikującej, ponieważ tak uznana technologia spawania powinna być honorowana przez inne jednostki certyfikujące. W tym celu należy skontaktować się z wybraną organizacją przeprowadzającą certyfikację i w zależności od wymagań złożyć odpowiedni wniosek. Złącza egzaminacyjne, przygotowane zgodnie z wytycznymi omawianej normy, wykonywane są na podstawie wstępnej instrukcji technologicznej spawania pWPS. Dokument ten tworzony jest na podstawie zapisów z prób spawania lub nabytego doświadczenia. Po wykonaniu złączy egzaminacyjnych oraz ich pozytywnej weryfikacji przez inspektora przekazywane są one do laboratorium. Jeżeli złącze egzaminacyjne nie spełnia wymagań stawianych przez normę, co jest weryfikowane przez inspektora jednostki certyfikującej, należy wykonać ponownie próbki. W przypadku pozytywnych wyników badań komplet dokumentów w formie protokołów należy dostarczyć do jednostki certyfikującej, która na ich podstawie sporządza protokół z zatwierdzonej technologii spawania WPQR. Na podstawie takiego dokumentu umożna opracować instrukcję technologiczną spawania WPS, a następnie zgodnie z odpowiednimi procedurami przekazać ją do produkcji. W przypadku tworzenia WPS należy pamiętać, że zawarte $\mathrm{w}$ nim istotne zmienne muszą być zgodne ze zmiennymi umieszczonymi w WPQR. W przeciwnym przypadku taki dokument może nie być zaakceptowany. $\mathrm{Na}$ rysunku 7 przedstawiono algorytm postępowania w przypadku zatwierdzania technologii spawania wg PN-EN ISO 15614-8.

\section{Przykład kwalifikowania technologii spawania płyt sitowych \\ z rurami wymiennika}

Przed przystąpieniem do kwalifikowania technologii spawania zgodnie z wymaganiami normy PN-EN ISO 15614-8 określono zmienne, które wpływają na przebieg procesu łączenia rur z płyta sitową. Zaliczono do nich:

- gatunki materiału podstawowego:

- płyta sitowa: stal P355NH; grupa materiałowa wg CR ISO 15608: 1.2,

- rury: austenityczna stal odporna na korozję 1.4404 (316L); grupa materiałowa wg CR ISO 15608: 8.1 ;

- metodę spawania: TIG (141) bez materiału dodatkowego;

- pozycję spawania: PA;

- rodzaj złącza oraz spoiny: spoina czołowa, brzegowa (BW),

- rodzaj spawania: ręczne;

- wymiary geometryczne rur: $\varnothing 12 \mathrm{~mm}, \mathrm{t}=1,5 \mathrm{~mm}$,

- wymiary geometryczne płyty sitowej: $t=10 \mathrm{~mm}$,

- układ rur (podziałka): trójkątny,

- zastosowane gazy osłonowe: I1 (100\% Ar) wg PN-EN ISO 14175 [22].

W kolejnym etapie przeprowadzono próby technologiczne spawania płyty sitowej z rurami z uwzględnieniem wytypowanych zmiennych istotnych. Ustalono warunki przygotowania złącza przed spawaniem oraz prądowe parametry spawania. Na podstawie zapisów z prób wykonano wstępną instrukcję technologiczną spawania pWPS, którą wykorzystano do spawania celowych próbek w obecności inspektora jednostki certyfikującej. W tablicy IV przedstawiono geometrię elementów przed spawaniem, kolejność spawania oraz zastosowane parametry spawania. Na rysunku 8 pokazano próbkę z rurami sczepionymi z płytą sitową, a na rysunku 9 wykonane złącze próbne.

Tablica IV. Parametry spawania złączy próbnych

Table IV. Parameters of welding of test joints

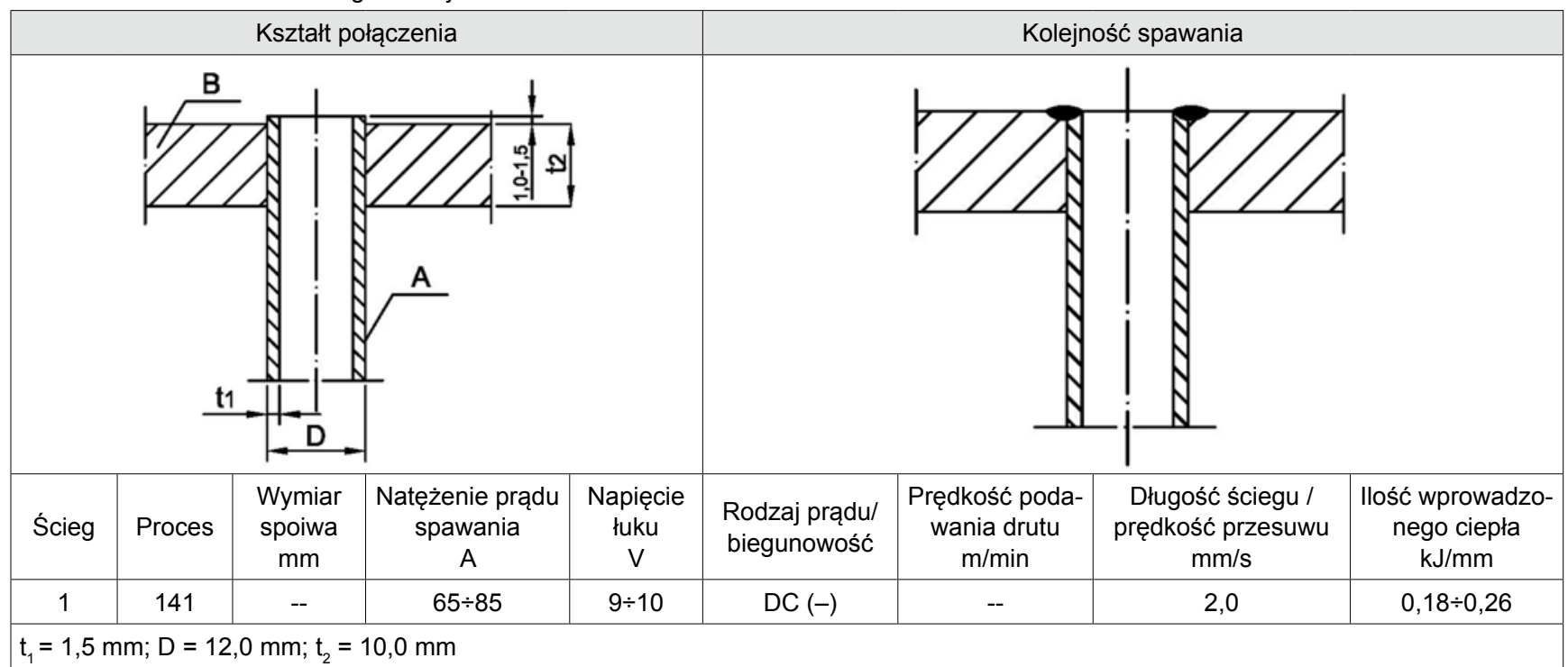




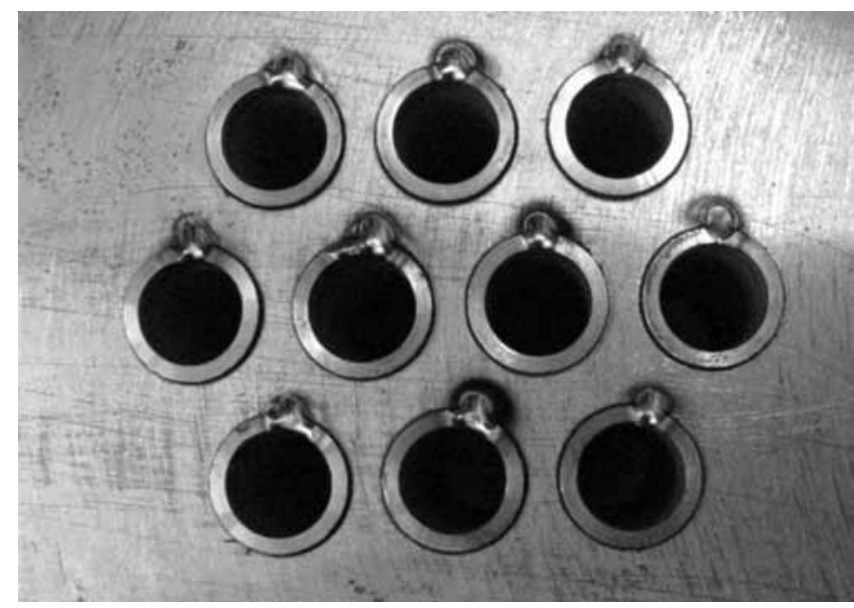

Rys. 8. Złącze próbne z układem trójkątnym rur, przygotowane do kwalifikowania technologii spawania zgodnie $z$ wytycznymi normy PN-EN ISO 15614-8

Fig. 8. Test joint with tube ends in triangular pitch prepared for qualification of welding procedure acc. to PN-EN ISO 15614-8 standard

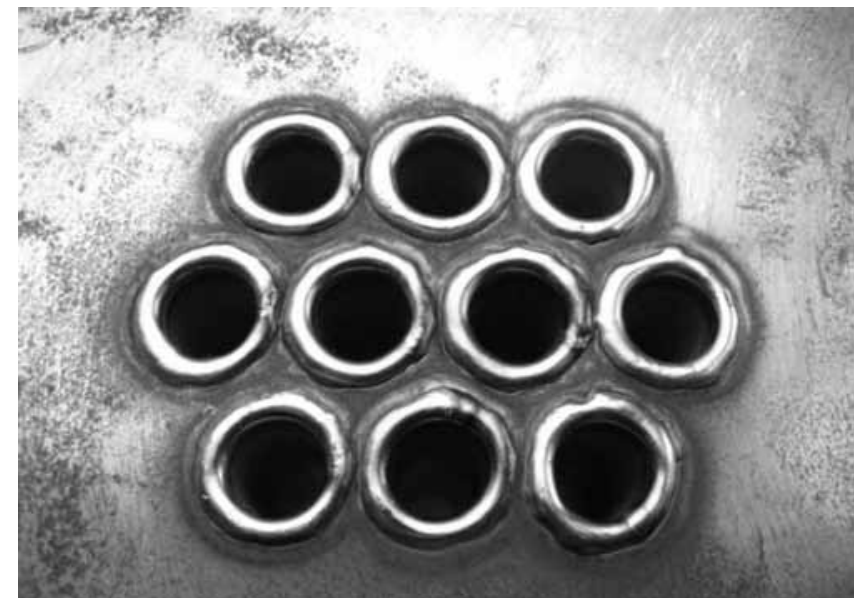

Rys. 9. Złącze próbne z układem trójkątnym rur, wykonane zgodnie $z$ wytycznymi podanymi $w$ tablicy IV

Fig. 9. Test joint with tube ends in triangular pitch welded acc. to parameters given in table IV

\section{Zakres i wyniki badań złączy próbnych}

$\mathrm{Na}$ podstawie wytycznych zawartych w normie PN-EN ISO 15614-8 oraz analizy specyfikacji technicznej dotyczącej projektowania określono następujący zakres badań:

- wizualne (VT),

- penetracyjne (PT),

- radiograficzne $(\mathrm{RT})$,

- makroskopowe.

\section{Badania wizualne}

Badania wizualne przeprowadzono zgodnie $z$ wymaganiami normy PN-EN 970 [22]. Badaniu poddano $100 \%$ spoiny i SWC. Wymagany poziom jakości ustalono na podstawie tablicy I zamieszczonej w pkt. 7.2.2 normy PN-EN ISO 15614-8. Badania wykonano bezpośrednio przy użyciu standardowego oprzyrządowania. $\mathrm{Na}$ ich podstawie nie stwierdzono występowania niezgodności spawalniczych, co pozwoliło na przekazanie wykonanej próbki do dalszych badań. Poziom akceptacji określono jako zgodny z tablicą I zamieszczoną w pkt. 7.2.2 omawianej normy.

\section{Badania penetracyjne}

Badania penetracyjne wykonano zgodnie $z$ wymaganiami normy EN 571-1 [23]. Badaniu poddano $100 \%$ wykonanych złączy spawanych. System preparatów do badań penetracyjnych był zgodny z EN 571-IICd-2. Nie stwierdzono żadnych wskazań świadczących o występowaniu niezgodności

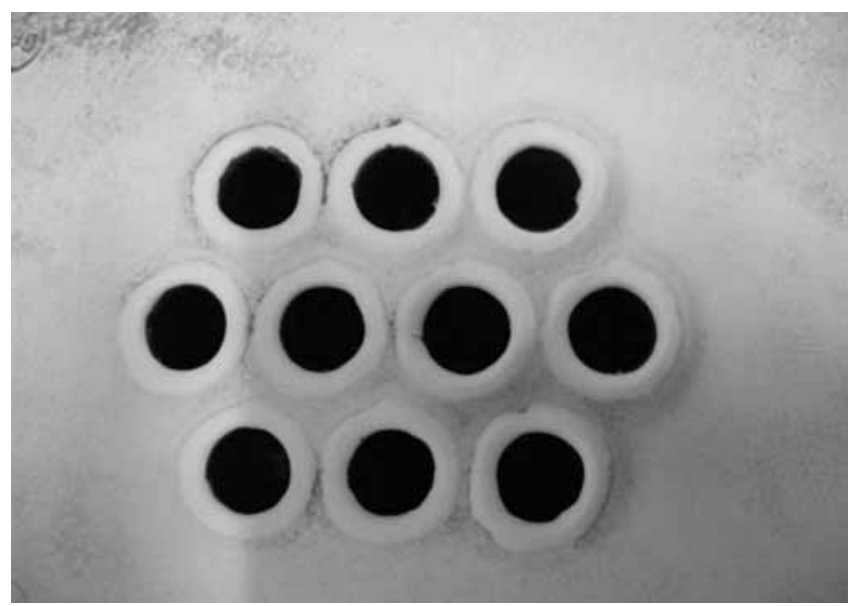

Rys. 10. Złącze próbne po wykonaniu badań penetracyjnych. Brak wskazań świadczących o występowaniu niezgodności spawalniczych Fig. 10. Test joint after penetration inspection. No mismatches are shown

spawalniczych. Złącze po badaniach penetracyjnych przedstawiono na rysunku 10.

W przypadku badań penetracyjnych tego rodzaju złącza należy zwrócić szczególną uwagę na bardzo dokładne oczyszczenie wnętrza rur z penetrantu. Nieodpowiednie oczyszczenie może być przyczyną nieprawidłowych wskazań. Zaleca się konsultacje $z$ inspektorem jednostki certyfikującej w celu ustalenia algorytmu przeprowadzania procedury, który musi być zgodny z wymaganiami normy EN 571-1.

\section{Badania radiograficzne}

Badania radiograficzne wykonano zgodnie z PN-EN 1435 [24]. Badano złącza spawane określone normą PN-EN ISO 15614-8, co wynika z tego, że żadne połączenie nie wymaga próby wyciskania. 
Poziom akceptacji ustalono zgodnie z wymaganiami zawartymi w tablicy II zamieszczonej w pkt. 7.2.4 normy PN-EN ISO 15614-8. Na podstawie analizy radiogramów nie stwierdzono występowania niezgodności spawalniczych.

\section{Badania makroskopowe}

Badania makroskopowe wykonano na podstawie wytycznych normy PN-EN 1321:2000 [25]. Na rysunkach 11 i 12 przedstawiono makrostrukturę złącza spawanego.

Nie stwierdzono obecności niezgodności spawalniczych w przekroju poprzecznym złączy. Spoiny były symetryczne $z$ łagodnie przechodzącym w materiał

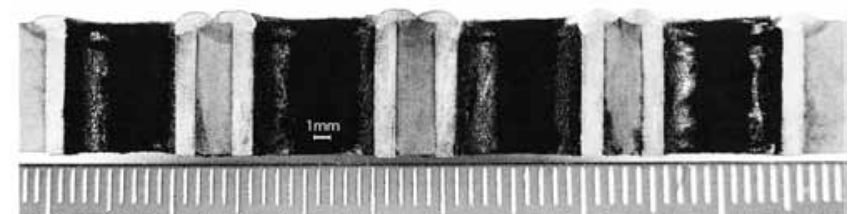

Rys. 11. Przekrój poprzeczny złącza spawanego rury ø $12 \times 1,5 \mathrm{~mm}$ z płytą sitową (4 rury), trawienie Ma11Fe

Fig. 11. Cross section of tubes to tube-plate test joints (4 tubes $\varnothing 12 \times 1,5 \mathrm{~mm})$, etching Ma11Fe rodzimy licem. Spoiny sczepne zostały poprawnie przetopione, a w miejscu ich występowania nie stwierdzono niezgodności spawalniczych.

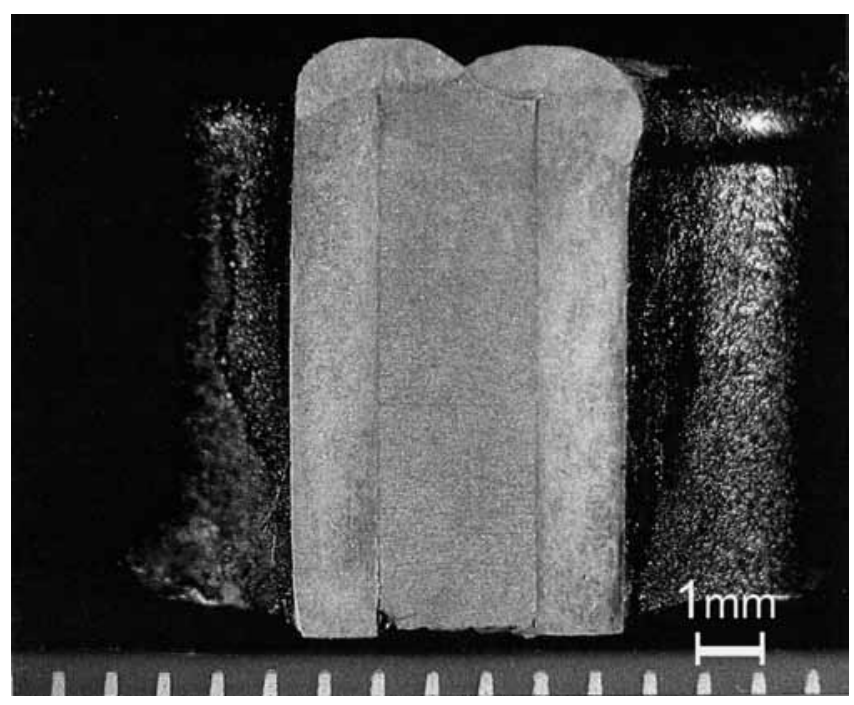

Rys. 12. Przekrój poprzeczny sąsiadujących krawędzi rury $\varnothing 12 \times 1,5 \mathrm{~mm}$ z płytą sitową, trawienie Ma11Fe

Fig. 12. Cross section of tube to tube-plate test joint (4 tubes $\varnothing 12 \times 1,5 \mathrm{~mm}$ ), etching Ma11Fe

\section{Podsumowanie}

Wykonane badania pozwoliły na zakwalifikowanie technologii spawania rur z płytą sitową dla popłaczenia materiałowego: stal austenityczna odporna na korozję ze stalą niestopową. Pozwoliło to na uzyskanie protokołu z zatwierdzonej technologii spawania WPQR oraz wykonanie na jego podstawie instrukcji technologicznej spawania (WPS). Proces został poprzedzony analizą zmiennych wpływających na proces spawania rur z płytami sitowymi, co umożliwiło dobór odpowiedniej geometrii złącza przed spawaniem oraz parametrów spawania. Zaproponowana technologia spawania została zakwalifikowana przez jednostkę certyfikującą. W przypadku zatwierdzania technologii spawania rur z płytami sitowymi należy zwrócić szczególną uwagę na układ rur (podziałkę) stosowanych w wymienniku ciepła oraz najmniejszą możliwą odległość pomiędzy zewnętrznymi krawędziami rur. Wpływa to na zakres uznanej technologii spawania. W rozważanym przykładzie zakres uznania jest następujący:

- metoda spawania: 141 ,

- rodzaj złączy i spoiny: spawanie rur z płytą sitową,
- grupy materiałowe: a) płyta sitowa: podgrupy 1.1, 1.2, b) rura: podgrupa 8.1 ,

- grubość materiału: a) płyta sitowa: $\geq 10 \mathrm{~mm}$ : b) grubość ścianki rury: 0,75 $\div 3 \mathrm{~mm}$,

- średnica zewnętrzna rury: $\mathrm{d}_{\mathrm{a}} \geq 12 \mathrm{~mm}$,

- odstęp: maks. 0,5 mm,

- rodzaj prądu i biegunowość: DC (-),

- pozycja spawania: PA,

- minimalny odstęp między dwoma rurami: $\mathrm{d}_{1} \geq 3 \mathrm{~mm}$.

W przypadku wykonywania tego rodzaju złączy należy zwrócić szczególną uwagę na stan powierzchni płyty sitowej oraz rur. Musi być ona wolna od zanieczyszczeń. Nieprzestrzeganie tego standardowego zabiegu powoduje tworzenie się w spoinie niezgodności spawalniczych, np. pęcherzy gazowych, które dyskwalifikują złącze. Jednocześnie koncentracja gazów w miejscu spawania utrudnia proces spawania (wypychanie jeziorka ciekłego metalu). Taka sytuacja może być związana z poprzedzającym proces spawania rozwalcowaniem rur, podczas którego używa się środków smarujących. 


\section{Literatura}

[1] PN-EN ISO 15614-8:2005. Specyfikacja i kwalifikowanie technologii spawania metali. Badanie technologii spawania. Część 8: Spawanie rur z płytami sitowymi.

[2] Rogalski G., Łabanowski J.: Kwalifikowanie technologii spawania zgodnie z wytycznymi normy PN-EN ISO 15613 na przykładzie wytwarzania rur stosowanych w płaszczowo-rurowych wymiennikach ciepła. Biuletyn Instytutu Spawalnictwa 5/2011.

[2] Świerczyńska A., Rogalski G., Fydrych D.: Badania właściwości i struktury spawanych austenitycznych rur wymienników ciepła. Przegląd Spawalnictwa 6/2010.

[4] www.secespol.pl

[5] Hobler T.: Ruch ciepła i wymienniki. Wydanie V zmien. i uakt. WNT Warszawa 1979.

[6] ASME Sec. VIII div. I: 2010 ASME Boiler and Pressure Vessel Code, Section VIII, Division 1: Rules for Construction of Pressure Vessels.

[7] PN-EN 13445-3:2009: Nieogrzewane płomieniem zbiorniki ciśnieniowe. Część 3. Projektowanie (oryg.).

[8] ASME Sec. IX:2010 ASME Boiler and Pressure Vessel Code, Section IX: Welding and Brazing Qualifications.

[9] PN-EN ISO 15609-1:2007. Specyfikacja i kwalifikowanie technologii spawania metali. Instrukcja technologiczna spawania. Część 1. Spawanie łukowe.

[10] EN 287-1 (prEN ISO 9606-1): Spawalnictwo. Egzaminowanie spawaczy. Stale.

[11] EN 287-2: Spawalnictwo. Egzaminowanie spawaczy. Aluminium i stopy aluminium.

[12] PN-EN ISO 9606-3:2001. Egzaminowanie spawaczy. Część 3. Miedź i stopy miedzi.

[13] PN-EN ISO 9606-4:2001. Egzaminowanie spawaczy. Część 4. Nikiel i stopy niklu.
[14] PN-EN ISO 9606-5:2002. Egzaminowanie spawaczy. Część 5. Tytan i stopy tytanu, cyrkon i stopy cyrkonu.

[15] PN-EN 1418:2000. Personel spawalniczy. Egzaminowanie operatorów urządzeń spawalniczych oraz nastawiaczy zgrzewania oporowego dla w pełni zmechanizowanego i automatycznego spajania metali.

[16] PN-EN 29692:1997. Spawanie łukowe elektrodami otulony$\mathrm{mi}$, spawanie łukowe w osłonach gazowych i spawanie gazowe. Przygotowanie brzegów do spawania stali.

[17] PN-EN 1708-1:2010. Spawanie. Podstawowe rozwiązania stalowych połączeń spawanych. Część 1.

[18] CR ISO 15608:2002. Spawanie. Wytyczne systemu podziału materiałów metalowych na grupy.

[19] PN-EN ISO 15614-1:2008. Specyfikacja i kwalifikowanie technologii spawania metali. Badanie technologii spawania. Część 1: Spawanie łukowe i gazowe stali oraz spawanie łukowe niklu i stopów niklu.

[20] PN-EN 439:1999. Materiały dodatkowe do spawania. Gazy i mieszaniny gazów do spawania i procesów pokrewnych.

[21] PN-EN ISO 14175:2009. Materiały dodatkowe do spawania. Gazy i mieszaniny gazów do spawania i procesów pokrewnych.

[22] PN-EN 970:1999. Spawalnictwo. Badania nieniszczące złączy spawanych. Badania wizualne.

[23] PN-EN 571-1:1999. Badania nieniszczące. Badania penetracyjne. Zasady ogólne.

[24] PN-EN 1435:2001 Badania nieniszczące złączy spawanych. Badania radiograficzne złączy spawanych.

[25] PN-EN 1321:2000. Spawalnictwo. Badania niszczące metalowych złączy spawanych. Badania makroskopowe i mikroskopowe złączy spawanych.

\section{\$ 4 METAL.PL}

\section{Ponad 2000 podwykonawców z całego świata}

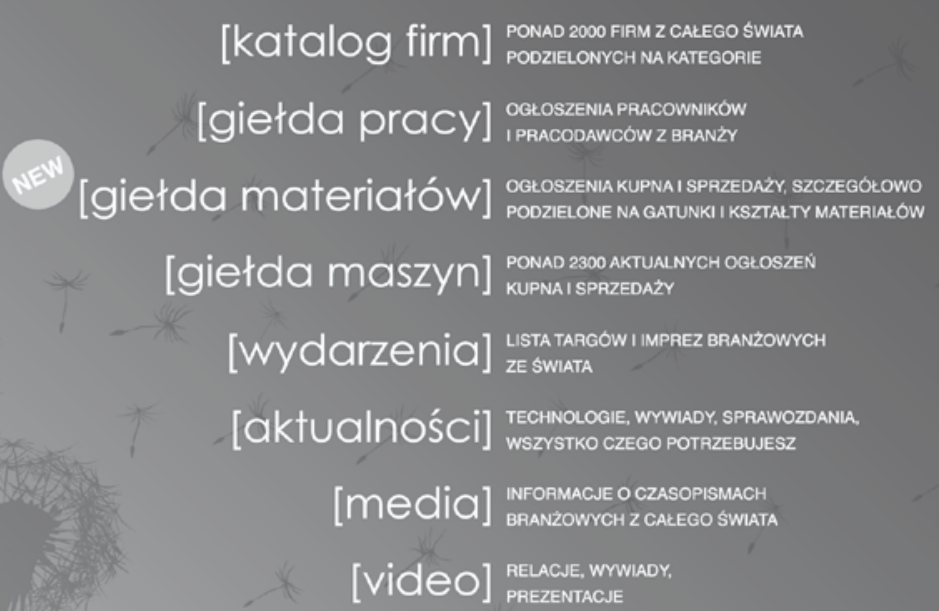

[katalog firm] PONAD 2000 FIRM Z CALEGO SWIATA

[giełda pracy] oceszena paacownurour
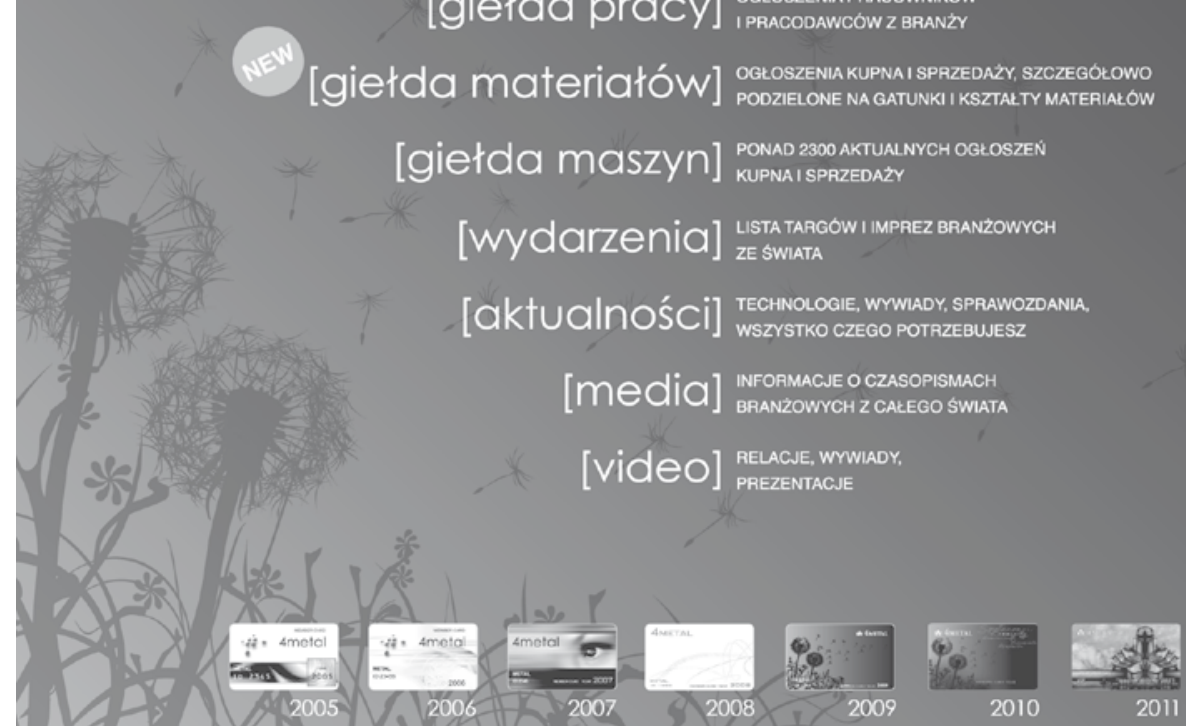

GET THE MEMBERSHIP 